- 3 безпечення сумісної роботи з р діост нціями, які були прийняті н озброєння р ніше т зн ходяться в експлу т ції;

- прийом н озброєння, як пр вило, р діост нцій вл сного виробництв бо з рубіжного н конкурсній основі;

- розробк прогр мов них р діост нцій, що з безпечує сумісну роботу з ур хув нням особливостей орг ніз ції р діозв'язку і ст нд ртів, які прийняті в різних кр їн.

озробк з собів $\mathrm{p}$ діозв'язку н принципово нових 3 с д х із вр хув нням цих тенденцій їх розвитку т осн щення ними військ бройних ил кр їни, безумовно, з безпечить необхідну якість зв'язку т ефективність бойового упр вління військ ми як у з г льновійськовому бою, т к і при проведенні спеці льних опер цій.

\section{писок літер тури}

1. врилов . овый мобильный пункт упр вления для соединений и ч стей морской пехоты / врилов // рубежное военное обозрение. - 2007. №4. $-.59-62$.

2. рпов . . остояние и перспективы р звития системы и войск связи ооруженных ил оссийской едер ции / . . рпов // вязь в ооруженных ил $х$ оссийской едер иии. -2007. - .17-22.

3. сной . втом тизиров нные системы упр вления ухопутными войск ми / . сной, . удков // рубежное военное обозрение. - 2003. № 9. $-.25-32$.

4. рченко . овременное состояние $u$ перспективы $p$ звития $p$ диост нций з рубежных госуд рств / . рченко // рубежное военное обозрение. - 2003. - № 6. - . 22 - 30.

дійшл до ред кцї 18.12.2008

ецензент: доктор технічних н ук, професор . . вчук, ьвівський інститут ухопутних вій ськ ціон льного університету « ьвівськ політехнік », ьвів.

. . оролев, . . учук, . . ужняк, . . ст пчук

роведен н лиз р звития мобильных средств р диосвязи опер тивно -m ктического и $m$ ктического звен упр вления вооруженных сил ведущих стр н мир. ыявлены тенденции их р звития. пределены подходы к р зр ботке нового поколения мобильных р диост нций.

лючевые слов : $p$ диост нция, , SINCGARS, JTRS.

\title{
ANALYTICAL REVIEW OF DEVELOPMENT OF MOBILE COMMUNICATION FACILITIES OF OPERATIVE AND TACTICAL CONTROL LEVEL S OF LEADING COUNTRIES ARMED FORCES
}

\section{M. Korolev, E. V. Luchuk, V. V. Luzhnyak, . S. Ostapchuk}

The analysis of development of radio mobile facilities of operative and tactical control level of leading countries armed forces is conducted. Their progress trends are exposed. Ways of development of new generation of the mobile radio stations arecertained.

Keywords: radio station, FHSS, SINCGARS, JTRS.

\subsection{9}

• . оліщук, . . ілімонов

ввівський інститут ухопутних військ, ввів

ст тmі н лізуеться ст н спр в з упр вління бойовими діями збройних сил $\quad$ інших держ в у різних л нк х упр вління (від стр тегічної до $m$ ктичної) н полі бою із з стосув нням передових інформ ційних технологій.

лючові слов : системи упр вління, єдиний інформ ційний простір, інформ ційн мереж, мережсецентричні війни.

\section{сту I}

ост новк проблеми. ьогодні пит ння упр вління військ ми і бойовими діями 3 використ нням з собів втом тиз ції тісно пов 'яз ні 3 пит ннями інформ ційної боротьби. ро кту льність цієї проблеми свідчить 8-м щорічн міжн родн конференція нституту оборонного i урядового розвитку (IDGA) , що відбул ся у шингтоні 27-30 січня 2009 року, присвячен мережецентричним опер ціям. конференції в числі 6 г тьох розгляд лися пит ння вдоскон лення мережевих систем упр вління і зв'язку, т кож

( ) . . оліщук, . . ілімонов 
концепція системи сумісності і вз ємодії різних елементів у мережі нез лежно від їх військової і н ціон льної прин лежності.

н ліз ост нніх досліджень і публік цій. ост нні роки з'явилось б г то публік цій в російських вид ннях [1-4] і вид ннях інших кр їн $[5,6]$, які присвячені проблемі з стосув ння мережевих інформ ційних технологій для ведення бойових дій.

перше інформ ційні технології як 3 соби ведення бойових дій були використ ні у війні проти р ку в 1991 році, термін «інформ ційн війн » офіційно - в директиві міністр оборони від 21 грудня 1992 року. 1996 році ент гон 3 твердив доктрину інформ ційної війни (« октрин боротьби систем ми контролю і упр вління»), в 1998 році міністерство оборон и вводить в дію « б'єдн ну доктрину інформ ційних опер цій». гідно 3 ост нньою інформ ційн війн визн ч ється як «комплексн дія (сукупність інформ ційних опер цій) н систему держ вного і військового упр вління противник , н його військово-політичне керівництво 3 метою ухв лення ним вже в мирний ч с сприятливих для кр їни-ініці тор інформ ційної дії рішень і повної п р ліз ції інфр структури упр вління противник в ході конфлікту».

роект ент гон « ойові системи м йбутнього» передб ч $є$ досягнення збройними сил ми до 2010 року повної інформ ційної перев ги н д будь-яким противником. думку ф хівців цієї г лузі, ур ження в інформ ційній війні може н довго (якщо не н $з$ вжди) відкинути кр їну, що прогр л , н з д в ії розвитку, кр їн переможець діст не необмежені можливості упр в ляти переможеними, при цьому тр нсформуючи поняття «поле бою» в поняття «бойовий простір».

етою ст тті $€$ н ліз існуючих i перспективних мережевих систем упр вління бойовими діями збройних сил $\mathrm{T}$ інших держ в у різних л нк х упр вління (від стр тегічної до т ктичної) н полі бою (бойовому просторі) 3 3 стосув нням передових інформ ційних технологій, їх уз г льнення і систем тиз ція.

\section{сновний м тері л}

ійськове керівництво в якості одного 3 основних н прямків своєї діяльності з підвищення бойових можливостей об'єдн них збройних сил i підготовки їх до проведення спільних опер цій в

столітті в кінці 90-х років минулого століття визн чило ре ліз цію концепції ведення воєнних дій в єдиному інформ ційному просторі бо 3 використ нням об'єдн них інформ ційно-керов них мереж (NCW - Network-Centric Warfare) [3].

$$
\text { відповідності з цією концепцією }
$$

передб ч ється 3 допомогою 3 безпечення військ передовими інформ ційними технологіями (високопродуктивних комп'ютерів, суч сного прогр много з безпечення, цифрових систем перед чі д них) об'єдн ти розосереджені в широкому бойовому просторі різнорідні сили i 3 соби (особовий скл д, орг ни і пункти упр влінн я, бойового з безпечення, зброю і військову техніку н земного, повітряного і морського б зув ння) в

б'єдн ння з високою мережевою рхітектурою глоб льні і лок льні інформ ційні мережі (рис. 1). оцінк ми експертів з ент гон , ці об'єдн ння порівняно з тр диційними будуть м ти безумовну перев гу із безпеч ть:

- створення в ре льному м сшт бі ч су єдиної к ртини опер тивно-т ктичної обст новки;

- зн чне скорочення ч су доведення інформ ції від системи розвідки до з собів вогневого ур ження;

- зн чне випередження противник в прийнятті i викон нні рішень, пл нув нні воєнних дій;

- прискорену концентр цію розосереджених у бойовому просторі різних з собів ур ження для н несення уд рів по в жливих об'єкт х і цілях противник .

чікується, що в результ ті ре ліз ції цих можливостей бойов ефективність об'єдн нь 3 мережевою рхітектурою порівняно 3 існуючими виросте б г тор зово.

ьогодні у збройних сил $\mathrm{x}$ проводяться 3 ходи 3 розвитку системи упр вління бойовими діями. прямки діяльності в цій сфері викл дені в прийнятій концепції « истеми упр вління, зв'язку, розвідки і комп'ютерного з безпечення для уч сників бойових дій» (Command, Control, Communications, Computers and Intellegence for the Warrior) [1].

о цих н прямків н леж ть:

- з безпечення опер тивно-технічних можливостей для орг ніз ції вз ємодії і спільного бойового використ ння різнорідних сил і з собів у р мк х єдиної структури упр вління (головний н прямок);

- широке 3 стосув ння втом тизов них систем упр вління ( ), які м ксим льно виключ ють ступінь уч сті людини у зборі, обробці, н лізі й розподілі інформ ції і з безпечують підвищення ефективності опер тивного упр вління військ ми 3 критеріями: поінформов ність, коректність рішень, які прийм ються, вигр ш у ч сі; з безпечення підвищеної стійкості упр вління військ ми у будьяких умов х обст новки 3 р хунок живучості, н дійності, 3 в достійкості т інформ ційної 3 хищеності з собів;

- м ксим льно можливе з стосув ння ост нніх досягнень н уки і техніки в г лузі телекомунік цій, т кож готових комерційних ст нд ртів і п р тно- 
прогр мних з собів із метою скорочення термінів проектув ння і введення в дію нових систем.

ході ре ліз ції цієї концепції створюється «систем систем», як включ є в себе три скл дові .

ерш скл дов з безпечує ком ндув ння первинною інформ цією, як поступ є від джерел, що діють н всьому просторі бойових дій.

он уз г льнюе ці відомості для того, щоб н д ти ком ндув нню всіх рівнів єдину інформ ційну к ртину про ст н сил (як своїх, т к і противник ) і про н вколишнє середовище (в тому числі метеоумови, ст н поверхні земельного покриття і гідрологічні умови моря, т кож умови розповсюдження електром гнітних хвиль різних ді п зонів у цьому р йоні).

руг скл дов призн чен для збору, обробки, об'єдн ння й н лізу первинних д них, т кож для збереження їх і перед чі з з пит ми користув чів. відміну від первинної ця інформ ція отрим н в результ ті кл сифік ції цілей, розподілу по них зброї і відпр цюв ння д них н ведення. ким чином ця систем н повнюе тривимірний інформ ційний простір поля бою д ними пл нув ння бойових дій, упр вління і стрільби 3 метою досягнення перев ги н д противником.

ретя скл дов включ $є$ в себе з соби, які 3 безпечують з стосув ння зброї $\mathrm{T}$ ур ження об'єктів високоточними боєприп с ми. допомогою високоточної зброї 3 вд ється ряд точних уд рів, дія яких доповнює 3 стосув ння звич йних з собів ур ження. 3 ефективністю ур ження цілей прирівнюється до т ктичної ядерної зброї.

інцевим результ том ре ліз ції прогр ми 3 вк 3 ними н прямк ми є створення єдиної інформ ційно-керов ної структури, зд тної з безпечити центр лізов не упр вління в ре льному м сшт бі ч су діями всіх видів збройних сил як в широком сшт бних війн х, т к і в регіон льних конфлікт $\mathrm{x}$, вільний доступ користув чів до ресурсів системи, т кож оптиміз цію процесів обробки й обміну д них в усіх л нК х упр вління військ ми.

вдячуючи з пров дженню цієї структури, н ведення і з стосув ння зброї буде здійснюв тись 3 високим ступенем н дійності т опер тивності, що не дозволить противнику вжити декв тних відповідних з ходів. снуючі т перспективні військ ми збройних сил кр їн н ведені в т блиці. опер тивно-стр тегічній л нці упр вління вводиться в дію глоб льне

(GCCS), в якій ре лізується новий стр тегічний принцип: ур ження будь-якої цілі - у будь-якому $\mathrm{p}$ йоні - у будь-який ч с. опер тивно-т ктичній л нці упр вління інформ ційно-керов н інфр структур створюється в процесі ре ліз ції відповідних прогр м по вид $\mathrm{x}$.

сухопутних військ х - це прогр м « нтерпр йз» [1], як передб ч є:

- першочерговий розвиток 3 собів з безпечення безпосередньо уч сників бойових дій;

- широке використ ння з собів космічного 6 зув ння в інтерес х сухопутних військ;

- повну інтегр цію військових з собів збору, обробки і розподілу інформ ції;

- н рощув ння бойової ефективності зброї і військової техніки перев жно з р хунок впров дження ост нніх досягнень в г лузі інформ ційних технологій;

- зн чне розширення ділянок електром гнітного спектр , який використовується в інтерес х , тощо.

ьогодні у проводиться об'єдн ння існуючих і тих, що створюються, підсистем у вид $\mathrm{x}$ збройних сил $\mathrm{i}$ род $\mathrm{x}$ військ в єдину втом тизов ну систему упр вління військ ми 3 використ нням єдиного інформ ційного простору.

роводиться ктивн робот у сфері 3 пров дження суч сних інформ ційних технологій в р мк $\mathrm{x}$ розвитку втом тизов них систем упр вління, розвідки і зв'язку 4 (Command, Control, Communications, Computers and Intelligence System) 3 метою створити видову інформ ційнокеров ну мережу під н звою « ойов мереж сухопутних військ» (Land War Net), як буде охоплюв ти т ктичну л нку упр вління і н віть окремого солд т в зоні бойових дій у відповідності з прогр мою пр ктичної ре ліз ції основних положень концепції « едення бойових дій в єдиному інформ ційному просторі» [2].

ри ре ліз ції цієї концепції пл нується вирішити одне із головних з вд нь у сфері інформ ційно-комунік ційної підтримки системи упр вління - з безпечення зв'язку в мобільному в рі нті 3 виключенням н перспективу із орг ніз ційно-шт тної структури бриг д підрозділів, які призн чені тільки для з безпечення зв 'язку (рот і взводів зв'язку).

е я зн ходжусь? е мої сусіди? де противник? т ктичній л нці упр вління відповіді н ці з пит ння можн зн йти при формув нні інформ ційно-керов ної мережі під н звою « ктичний нтернет» ( ), як є невід 'ємним компонентом єдиної мережі LWN, що ктивно формується і у свою чергу входить до скл ду глоб льної інформ ційно-керов ної мережі ( ) [4]. 


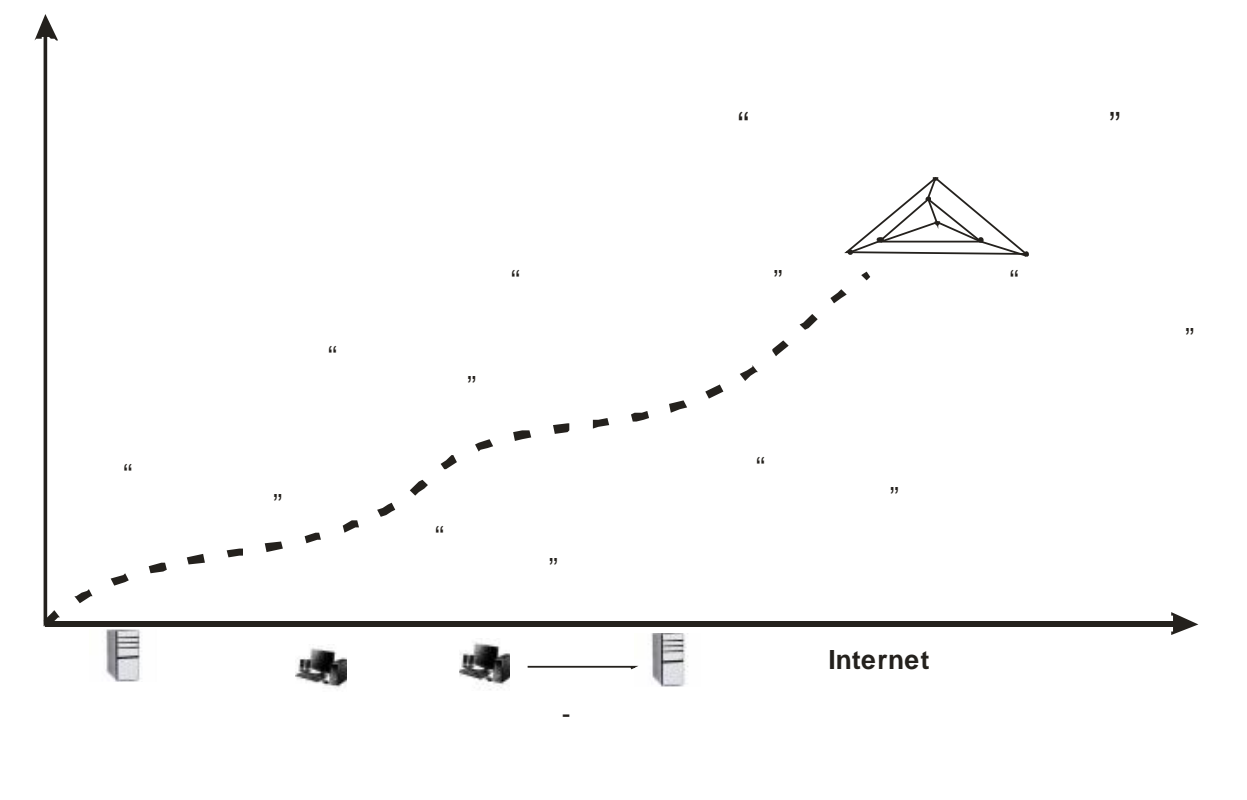

uc. 1. волюція технологій і перехід до мережецентр ичних опер цій

оєнні дії у цій мережі є лише різновидом мережевих процесів. егулярн рмія, всі види розвідок, технічні відкриття і високі технології, журн лістик і диплом тія, економічні процеси й соці льні тр нсформ ції, цивільне н селення і к дрові військові, регулярні військові ч стини й окремі сл босформов ні групи - все це інтегрується в єдину мережу, по якій циркулює інформ ція. військово-повітряних сил х $($ )

створен своя концепція перспектив розвитку інформ ційних і керов них систем під н звою « оризонт» [1]. он передб ч є здійснення повної втом тиз ції процесів перед чі інформ ції н всіх пункт х упр вління ком ндув ння , в орг н х упр вління ві цією, в розвідув льних і інформ ційних комплекс х н і створення н цій б зі об'єдн ної системи упр вління

под льшою іiї інтегр цією в єдину інформ ційно керов ну структуру збройних сил. е дозволить зн чно скоротити ч с збору, перед чі, обробки розвідд них і прийняття рішень. рийнято вв ж ти, що основу єдиної інформ ційно-керов ної структури скл д ють регіон льні системи упр вління діями ві ції у скл ді об'єдн них ком ндув нь в передових зон х.

днією 3 основних структур мерик нської системи упр вління космічними п р т ми ( ) різного призн чення $€$ ком ндно-вимірюв льний комплекс ( , AFSCN - Air Force Satellite Control Network) [4].

ей комплекс призн чений для з безпечення функціонув ння космічних військових систем (перед чі д них і зв'язку, виявлення пусків б лістичних $\quad$ кет, $\quad$ д діон віг ційної i метеорологічної), військових експеримент льних супутників, орбіт льних модулів космічних комплексів « ттл» і окремих цивільних штучних супутників землі ( ). соби комплексу використовуються під ч с з пусків космічних п р тів, крім того, при проведенні випробув ння різних взірців р кетної зброї н хідному,

хідному т ихооке нському $\mathrm{p}$ кетних полігон $\mathrm{x}$ (мис н вер л, шт т лорид, ві ційн 6 з нденберг, шт т ліфорнія i ркинг-сендз, о. у ї, шт т в йї).

допомогою

здійснюється

контроль п р метрів руху штучних супутників емлі, прийом і обробк телеметрії, ді гностик й усунення неспр вностей в роботі бортових систем, перед ч ком нд і прогр м упр вління н ет п х з пуску, виведення н робочу орбіту, технологічних випробув нь і експлу т ції супутників.

користь удоскон лення рхітектури комплексу ведуться роботи зі створення єдиного б г тоцільового центру упр вління

MMSOC (Multi-Mission Satellite Operations Center) [5]. роект спрямов ний н формув ння структури, зд тної здійснюв ти ефективне центр лізов не упр вління супутник ми, тих, що нині функціонують, т кож перспективних військових, цивільних і комерційних орбіт льних угрупов нь. рім того, новий центр упр вління повинен з безпечити функціонув ння військово експеримент льних у р мк х прогр м досліджень у сфері розробки перспективних космічних систем. ериторі льно цей об'єКт пл нується розмістити н рівер, ввести в дію в 2011 році. 
снуючі терспективні втом тизов ні системи упр вління військ ми збройни хсил кр їн

\begin{tabular}{|c|c|c|c|}
\hline $\begin{array}{c}\text { йменув ння } \\
\text { держ в }\end{array}$ & оротк х р ктеристик & НК 3 стосув ння & $\begin{array}{l}\text { якому ст ні } \\
\text { зн ходиться }\end{array}$ \\
\hline $\begin{array}{l}\text { лоб льн } \\
\text { GCCS }\end{array}$ & $\begin{array}{l}\text { ля попередження й оповіщення про н п д; контро- } \\
\text { лю з приведенням в різні ступені бойової готов - } \\
\text { ності; пл нув ння т керівництв бойовими діями; } \\
\text { формув ння т н лізу єдиної к рти опер тивної } \\
\text { обст новки; н д ння ком ндув нню необхідної } \\
\text { опер тивно-стр тегічної і довідкової інформ ції }\end{array}$ & $\begin{array}{l}\text { пер тивно- } \\
\text { стр тегічн л нк } \\
\text { упр вління } \\
\text { збройними сил ми }\end{array}$ & $\begin{array}{l}\text { водиться } \\
\text { в дію }\end{array}$ \\
\hline $\begin{array}{l}\text { NCW (Network Centric } \\
\text { Warfare) }\end{array}$ & $\begin{array}{l}\text { дин систем розвідув льно-інформ ційного } \\
\text { з безпечення і бойового упр вління }\end{array}$ & $\begin{array}{l}\text { тр тегічн л нК } \\
\text { упр вління }\end{array}$ & $\begin{array}{l}\text { рийнят н } \\
\text { озброєння }\end{array}$ \\
\hline $\begin{array}{c}\text { FBCB2 (Force XXI Battle } \\
\text { Command Brigade or } \\
\text { Below) }\end{array}$ & $\begin{array}{c}\text { ля вид чі н дисплей комп'ютер ком ндир } \\
\text { бойової обст новки з прив'язкою до рельєфу } \\
\text { місцевості. истем збир є т розподіляє } \\
\text { інформ цію від супутників, літ ків, вертольотів, } \\
\text { т нків, } \quad \text { і окремих піхотинців } \\
\end{array}$ & $\begin{array}{c}\text { нформ ційн } \\
\text { систем бойового } \\
\text { упр вління в л нці } \\
\text { бриг д -б т льйон- } \\
\text { рот } \\
\end{array}$ & $\begin{array}{c}\text { ройшл } \\
\text { випробув ння }\end{array}$ \\
\hline-3( & пр вління тиловим з безпечення м н & сі орг ни тилу & $\begin{array}{l}\text { рийнят н } \\
\text { озброєння }\end{array}$ \\
\hline $\begin{array}{l}\text { MTC (Army Movement } \\
\text { Tracking System) }\end{array}$ & $\begin{array}{r}\text { ля з безпечення контролю з пересув нням } \\
\text { н земної бойової техніки і синхроніз ції ії дії }\end{array}$ & $\begin{array}{c}\text { истем } \\
\text { відслідковув ння } \\
\end{array}$ & $\begin{array}{l}\text { іял у війні з } \\
\text { р ком }\end{array}$ \\
\hline $\begin{array}{c}\text { истем упр вління, } \\
\text { розвідки т зв'язку } \\
\text { « нтерпр йз» }\end{array}$ & $\begin{array}{l}\text { ля зн ходження, втом тичного розпізн в ння і } \\
\text { супроводження декільк тисяч повітряних і н - } \\
\text { земних цілей, втом тичного н ведення керов ної } \\
\text { зброї н сотні цілей; з безпечення ком ндирів всіх } \\
\text { л нок електронними к рт ми поточної обст новки }\end{array}$ & $\begin{array}{c}\text { пер тивно- } \\
\text { т ктичн л нк , по } \\
3 \text { соб х упр вління - } \\
\text { до бриг ди т } \\
\text { окремого солд т }\end{array}$ & $\begin{array}{l}\text { л нується } \\
\text { повне } \\
\text { введення в дію } \\
\text { в } 2015 \text { р. }\end{array}$ \\
\hline LWN (Land War Net) & $\begin{array}{c}\text { истем упр вління, розвідки і зв 'язку сухопутних } \\
\text { військ }\end{array}$ & $\begin{array}{l}\text { ктичн л нк } \\
\text { упр вління }\end{array}$ & $\begin{array}{c}\text { ст ні } \\
\text { випробув нь }\end{array}$ \\
\hline $\begin{array}{l}\text { нформ ційно-керов н } \\
\text { мереж « ктичний } \\
\text { нтернет» }\end{array}$ & $\begin{array}{c}\text { евід’ємний компонент єдиної мережі сухопутних } \\
\text { військ } \quad \text { LW N }\end{array}$ & нк бриг д -взвод & $\begin{array}{l}\text { ипробув н в } \\
\text { зоні бойових } \\
\text { дій } \\
\end{array}$ \\
\hline « кФ йр» ( & $\begin{array}{c}\text { пр вління вогнем ртилерії т т ктичними } \\
\text { р кет ми } \\
\end{array}$ & $\begin{array}{l}\text { л нці б т рея - } \\
\text { груп } \quad \text { ртилерії }\end{array}$ & $\begin{array}{l}\text { рийнят н } \\
\text { озброєння }\end{array}$ \\
\hline 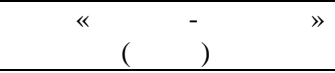 & $\begin{array}{cc}\text { пр вління } & \text { зенітно- ртилерійськими } \\
\text { бриг д ми і груп } & \text { ми до дивізіонів і б т рей } \\
\end{array}$ & КТичн л нК & $\begin{array}{l}\text { рийнят н } \\
\text { озброєння }\end{array}$ \\
\hline $\begin{array}{l}\text { втом тизов н систем } \\
\text { бойового упр вління } \\
\text { ві цією ( }) \text { н } \\
\text { ( фг ніст н) TBMCS } \\
\end{array}$ & $\begin{array}{c}\text { ля збору, обробки і розподілу розвідув льних } \\
\text { д них, пл нув ння повітряних опер цій, } \\
\text { опер тивного упр вління з'єдн ннями т } \\
\text { ч стин ми військово-повітряних сил }\end{array}$ & $\begin{array}{l}\text { истем бойового } \\
\text { пл нув ння і } \\
\text { упр вління ві цією } \\
\text { н }\end{array}$ & $\begin{array}{l}\text { рийнят н } \\
\text { озброєння }\end{array}$ \\
\hline AWACS & $\begin{array}{ccc}\text { истем бойового упр вління уд рною ві цією н } \\
\text { б зі літ ків } & \text { т упр вління } & -3 \\
\end{array}$ & стосовується н & $\begin{array}{l}\text { рийнят н } \\
\text { озброєння }\end{array}$ \\
\hline $485 \mathrm{~L}($ & $\begin{array}{l}\text { пр вління т ктичною ві цією при підт римці } \\
\text { військ і н несенні уд рів по об 'єкт х }\end{array}$ & $\begin{array}{ccc}\text { Ктичн } & \text { л нк } \\
\text { упр } & \text { вління } & \text { ві цією } \\
\end{array}$ & $\begin{array}{l}\text { рийнят н } \\
\text { озброєння }\end{array}$ \\
\hline $\begin{array}{l}\text { истем в3 ємодії } \\
\text { т зв'язку } \\
\ll \text { оперник» }\end{array}$ & $\begin{array}{c}\text { ля з безпечення повної втом тиз ції пл нув ння } \\
\text { і прийняття рішень ком ндув ннями т шт б ми } \\
\text { опер тивних об'єдн нь т з’єдн нь } \\
\text { ч стин ми і підрозділ ми морської піхоти }\end{array}$ & $\begin{array}{l}\text { і морськ } \\
\text { піхот }\end{array}$ & $\begin{array}{l}\text { водиться } \\
\text { повністю в } \\
2010 \text { р }\end{array}$ \\
\hline $\begin{array}{l}\text { NNEC (NATO Network } \\
\text { Enabled Capability) }\end{array}$ & $\begin{array}{l}\text { дин систем розвідув льно-інформ ційного } \\
3 \text { безпечення і бойового упр вління }\end{array}$ & & $\begin{aligned} & \text { ст ні } \\
& \text { відпр цюв ння }\end{aligned}$ \\
\hline TCRCCES $(\quad)$ & $\begin{array}{c}\text { ля з безпечення інформ ції про ст н здоров 'я } \\
\text { особового скл ду, пересув ння пор нених і хворих }\end{array}$ & $\begin{array}{l}\text { илов тр нспортн } \\
\text { систем }\end{array}$ & $\begin{array}{l}\text { ипробув н у } \\
\text { війні } 3 \text { р ком }\end{array}$ \\
\hline « ейдЖ» ( & $\begin{array}{r}\text { пр вління } 3 \text { соб ми } \\
\text { сектор } x\end{array} \quad$ в зон х, p йон х i & & $\begin{array}{c}\text { рийнят н } \\
\text { озброєння }\end{array}$ \\
\hline « $\mathrm{K} \mathrm{pc»(}$ & пр вління уд рними ядерними сил ми & $\begin{array}{l}\text { о б т реї , } \\
\text { еск дрильї літ ків- } \\
\text { носіїв т ві носців }\end{array}$ & $\begin{array}{l}\text { рийнят н } \\
\text { озброєння }\end{array}$ \\
\hline $\begin{array}{l}\text { « } »(\quad) \\
\ll \operatorname{pBic}((\quad)\end{array}$ & пр вління військ ми & $\begin{array}{r}\text { л нці б т льйон- } \\
\text { рмійський корпус }\end{array}$ & $\begin{array}{l}\text { рийнят н } \\
\text { озброєння }\end{array}$ \\
\hline 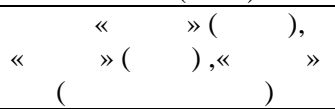 & пр вління т ктичними з'єдн ннями кор блів & & $\begin{array}{l}\text { рийнят н } \\
\text { озброєння }\end{array}$ \\
\hline$\ll \quad \mathrm{cB}_{\mathrm{B}} \gg\left(\begin{array}{l}(\quad) \\
\quad)^{\prime}\end{array}\right.$ & $\begin{array}{c}\text { пр вління літ к ми п лубної ві ції т } \\
\text { р діолок ційного виявлення }\end{array}$ & & $\begin{array}{l}\text { рийнят н } \\
\text { озброєння }\end{array}$ \\
\hline DACCIS ( нія) & $\begin{array}{c}\text { истем пл нув ння опер цій і упр вління } \\
\text { військ ми }\end{array}$ & $\begin{array}{l}\text { ід б т льйону і } \\
\text { вище }\end{array}$ & $\begin{array}{l}\text { рийнят н } \\
\text { озброєння }\end{array}$ \\
\hline
\end{tabular}

(C) . . олішук, . . ілімонов 
квітні 2008 року н ві 6 зі в шт ті ев д проведені н вч ння, н яких відпр цьовув лися принципи вз ємодії сил і з собів різних родів військ в умов х, н ближених до бойових. н вч ннях був 3 діяний широкий спектр систем упр вління, цілен ведення, т кож бойових комплексів сухопутних військ, i н вЧ нь бул продемонстров н можл ивість перетворення винищув ч F-22A Raptor, в перспективі й інших «цифрових» бойових м шин у ключові вузли мережецентричної системи упр вління поля бою.

инищув чі F-22A Raptor під ч с н вч нь продемонструв ли можливість прийому і перед чі в ре льному м сшт бі ч су різної інформ ції ком нд, відобр жень, д ні про ерокосмічну обст новку, т кож коротких текстових повідомлень, якими пілоти могли обмінюв тися 3 допомогою вст новленого в $\quad$ к біні пілот сенсорного термін лу.

озпоч ті випробув ння т ктичних повітряних ком ндних пунктів ( ) модифік ції Block -2 н 6 зі вертольот UH-60L «лек ок» для орг ніз ції упр вління в л нці «дивізія-бриг д » [4]. икорист ння повинно зН чно підвищити можливості зі здійснення м невру н земними сил ми. метою підвищення можливостей 3 розвідув льно-інформ ційного з безпечення бойових дій бортове електронне обл дн ння повинно одноч сно з безпечити прийом т обробку розвідув льних д них від різних джерел, в тому числі літ ків -8 « жист рс» i безпілотних літ льних п р тів (в перспективі пл нується орг нізув ти з борту упр вління розвідув льними ) і нег йну перед чу в цифровому з в доз хищеному режимі мовної $\mathrm{T}$ візу льної інформ ції про противник н н земні орг ни упр вління бо безпосередньо з соб м ур ження. борту кожного буде обл дн но п'ять втом тизов них робочих місць упр вління i розвідув льно-інформ ційного з безпечення бойових дій. в дослідні взірці були випробув ні в ході ведення бойових дій в р ку. військово-морських сил х ( )

пл ни створення єдиної інформ ційно-керов ної структури ре лізуються в р мк X ініці тиви « оперник», як передб ч $є$ з безпечення «безшовної» вз ємодії зв 'язку, розвідки і морської піхоти ( ) 3 под льшою їх інтегр цією в єдину систему для всіх . я структур повинн н б зі об'єдн ння розподілених кор бельних і берегових мереж з безпечити повну втом тиз цію процесів пл нув ння і прийняття рішень ком нду в нням і шт б ми опер тивних об 'єдн нь і з'єдн нь , т кож ч стин ми і підрозділ ми ерівництвом висунут

дод тКов концепція «інформ ційні технології століття», відповідно до якої передб ч ється до 2010 року розгорнути єдину глоб льну комп'ютерну мережу нтернет для т , як об'єдн є більше 150000 втом тизов них робочих місць [6]. ередб ч ється, що після повном сшт бного опер тивного розгорт ння мереж ст не головною телекомунік ційною системою дозволить з безпечити цифровий телефонний зв'язок, перед чу д них і відеоконференцзв'язок в інтерес х ком ндув нь, шт бів, сил і з собів і . цілому ця систем зд тн :

- у 10 р зів збільшити опер тивний р діус дій з'єдн ння кор блів;

- єдиний інформ ційний простір поля бою буде являти собою н півсферу р діусом більше 9000 км і висотою більше 40 км.

едеться розробк глоб льної системи тилового з безпечення GCCS, н яку покл д ється комплексне вирішення з вд нь поповнення з п сів боєприп сів і п льного, тр нспортного, фін нсового, медичного $\mathrm{T}$ інших видів тилового $\mathrm{T}$ технічного з безпечення. творено більше 40000 серверів i робочих ст нцій.

ом ндув ння

розр ховує отрим ти у своє розпорядження в 2010-2020 рр. якісно нову систему упр вління всім вид ми , як передб ч $\epsilon$ повну перев гу н д противником, що досяг ється не 3 р хунок перев ги сил і з собів, 3 р хунок створення необхідних умов для більш ефективного їх 3 стосув ння н віть в умов $\mathrm{x}$ недост тньої кількості сил і з собів [1].

ким чином, ент гон приступив до розгорт ння глоб льної інформ ційної мережі і пр ктичного відпр цюв ння технол огій нового типу війн - мережецентричної (мережевої) війни. бройні сили ця концепція розгляд є як мережецентричну орг ніз цію (рис. 2).

ережецентричн війн - це ведення воєнних дій, яке передб ч є підвищення бойового ст ну угрупов ння об'єдн них сил 3 р хунок створення інформ ційно-комут ційної мережі, як об 'єднує джерел інформ ції (розвідки), орг ни упр вління i 3 соби ур ження, що з безпечує доведення до уч сників опер цій достовірної і повної інформ ції про обст новку пр ктично в ре льному м сшт бі ч су. р хунок цього досяг ється прискорення процесу упр вління сил ми і з соб ми, підвищення темпів опер цій, ефективності ур ження сил противник , живучості своїх військ і рівня с мосинхроніз ції бойових дій.

творення єдиної системи розвідув льно інформ ційного з безпечення і бойового упр вління проводиться в тісній вз ємодії 3 


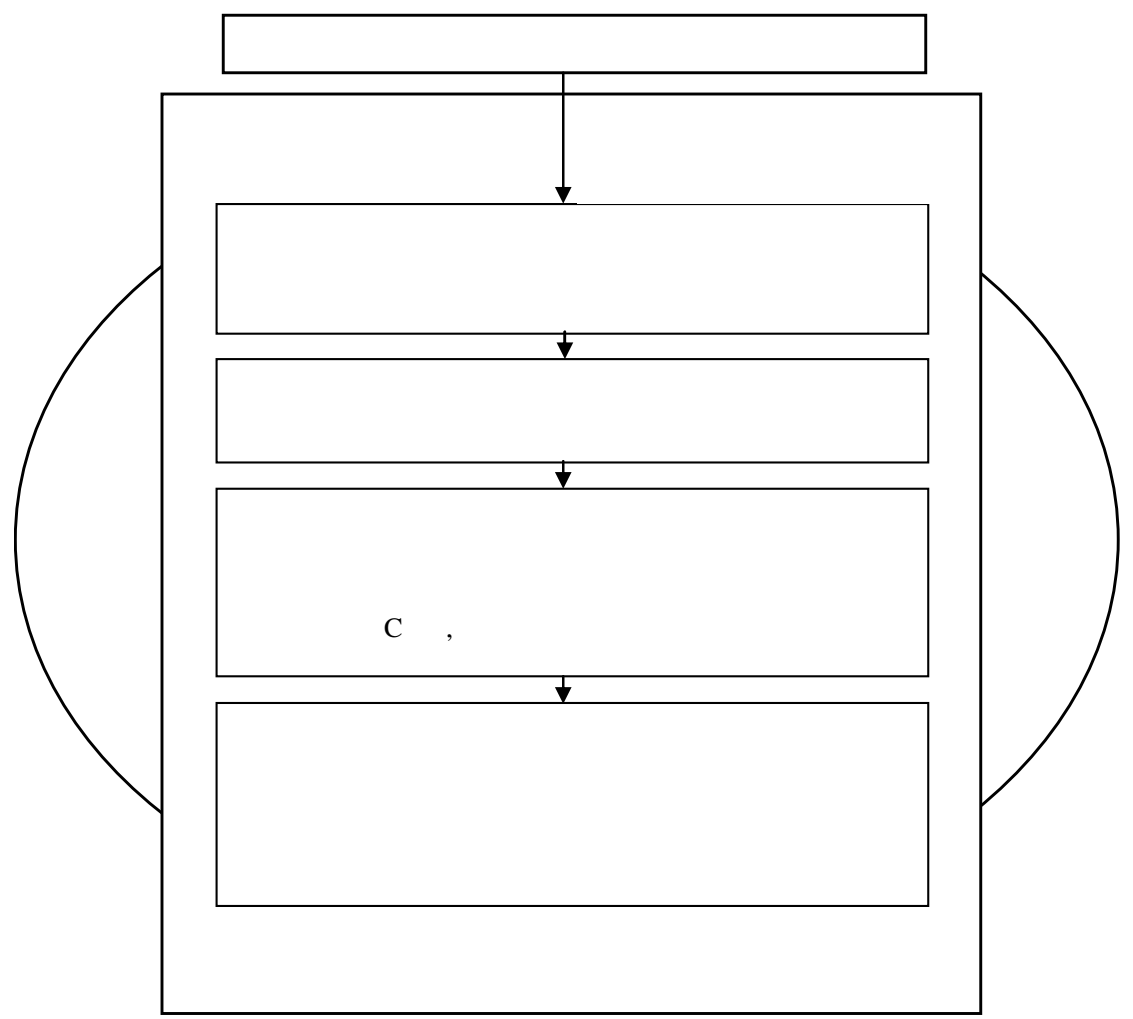

uc. 2. бройні сили як мережецентричн орг ніз ція

і н пр влене н 3 вч сне формув ння можливостей з н несення першими послідовної серії м сов них інформ ційних і високоточних вогневих уд рів, результ том яких повинн ст ти повн дезорг ніз ція бо знищення системи держ вного і військового упр вління противник .

p ктичн ре ліз ція б зових положень концепції ведення бойових дій 3 використ нням єдиного інформ ційного простору спрямов н в першу чергу н под льше ско рочення циклу «розвідк - уд р» як основного елемент концепції «OOD A LOOP» (Observe, Orient, Decide and Act OODA), що дет лізує й одноч сно об'єднує чотири процеси бойових дій - розвідку, (зн ходження), оцінку обст новки, прийняття рішення і н несення уд ру [3].

езв ж ючи н ряд відмінностей у тр ктув нні різними держ в ми поняття ключових положень $\mathrm{NCW}$, для розуміння в жливості вирішення проблем вз ємодії і сумісності систем упр вління в опер тивній пр ктиці ведення опер цій н ведемо цит ту із виступу колишнього верховного головноком ндув ч ом ндув ння стр тегічних досліджень дмір л жи мб сті ні: « безпечення необхідними технологіями для з безпечення безперервного обміну інформ цією в системі бойового упр вління $€$ вкр й в жливим елементом в ході ре ліз ції суч сних і перспективних форм і способів ведення бойових дій. ункціон льн сумісність втом тизов них систем розвідки, упр вління військ ми і зброєю, т кож з безпечення ст лої вз ємодії між ними розгляд ються в якості ключових компонентів, необхідних для досягнення інформ ційної перев ги в виробленні і прийнятті рішень, з метою рішучого випередження противник по всь ому циклу бойового упр вління».

оловний шт б об'єдн них сил в вропі (SHAPE) - 11 держ в-членів , підтрим в проект нії ATCCIS ( ійськов т ктичн систем упр вління і контролю інформ ції) - нової, високоефективної системи, призн ченої для обміну інформ цією [3].

езульт том ст ло створення моделі д них 3 елемент ми, ст нд ртними для бриг ди, дивізії i корпусу. підст ві цієї моделі і бул створен систем DACCIS для рмії нії. истем підтримує пл нув ння опер цій і упр вління військ ми від 6 т льйону i вище - до н ціон льного рівня, з безпечує інформ ційний обмін із союзник ми.

я систем допом г є польовим ком ндир м у викон нні м невру і з безпечення військ. истем охоплює всі види шт бної діяльності і роботи 3 особовим скл дом, підтримку прийняття рішень, пл нув ння опер цій, включ ючи вогневу підтримку, повітряні бої, вертолітні опер ції, т илове з безпечення, вз ємодію з цивільними служб ми.

(C) . . олішук, . . ілімонов 
р нції ре лізується концепція «інформ ційно-центричн війн » [3]. поч тку ця концепція ре лізовув л сь в $\mathrm{p}$ мК х прогр ми « ерспективн повітряно-н земн систем бойового упр вління», як дозволяє об'єдн ти різні бойові пл тформи для здійснення 3 ходів комплексного вогневого ур ження цілей.

ундесвер т кож пр цює н д створенням перспективної системи осн щення т озброєння особового скл ду, що дозволяє ре лізув ти нові концепції упр вління і зв'язку між бойовими формув ннями i вищими орг н ми упр вління. оботи, які проводяться, включ ють розробку перспективних з собів розвідки, персон льних комп'ютерних систем, систем упр вління і зв'язку типу «т ктичний нтернет», які дозволяють орг нізув ти вз ємодію між н логовими з соб ми зв'язку і цифровими систем ми перед чі д них. еликобрит нії формується своя глоб льн інформ ційн структур , як являє собою єдину інформ ційно-керов ну мережу зі спеці лізов ними систем ми безпеки т єдиним прогр мним з безпеченням. м йбутньому можливості інформ ційної інфр структури, що формується, пл нується розширити і для орг ніз ції вз ємодії т з безпечення доступу до інформ ційних ресурсів збройних сил союзників: , н ди, ової ел ндії й встр лії.

енер льний шт б збройних сил зр їлю розгляд $є$ втілення інформ ційних технологій як невід'ємний i обов'язковий трибут суч сних i м йбутніх опер цій. прикл д, під ч с ост нньої війни 3 ів ном 3 стосовув в перспективну систему упр вління і зв'язку Tzayad, як дозволяє об'єдн ти в угрупов ння різні для вирішення 3 вд нь пошуку i знищення мобільних $p$ кетних пускових уст новок, які з стосовув лись бойовик ми руху « езболл х». ійськові експерти відміч ють високу ефективність дій ізр їльських бриг д, озброєних т кою системою [3].

ост нніх документ $\mathrm{x}$ рмії ит ю зустріч ється термін «інтегров н мере жев і електронн війн » (INEW) [4]. он $\epsilon$ відобр женням суч сної кит йської концепції, яку можн порівняти 3 «мережецентричною війною (опер цією)» . я кит йськ концепція передб ч є проведення як н ступ льних, т к і оборонних дій. зом із тим мерик нські військові н літики відзн ч ють у ній перев гу перших н д другими. $\quad$ м мк $\mathrm{x}$ ре ліз ції концепції здійснюється розробк л зерної зброї для боротьби з космічними п р т ми вірогідного противник , т кож своїх н віг ційних систем космічного 6 зув ння, відпр цьовуються пит ння створення систем упр вління, зв'язку і розвідки, які повинні дозволяти з стосовув ти б лістичні р кети в неядерному осн щенні для боротьби 3 ві носними угрупов ннями

йбільш в жливими н прямк ми в будівництві збройних сил осійської едер ції $€$ створення нових перспективних і удоскон лення існуючих систем упр вління, пошук нових підходів в орг ніз ції зв'язку. ьогодні ведуться роботи 3 переозброєння системи зв'язку н цифрові системи перед чі д них н підст ві 3 стосув ння суч сних інформ ційних і телекомунік ційних технологій.

збройних сил х створюється перспективн систем військової розвідки. озпоч лось використ ння «бойового нтернету» [4]. вич йно, т кі прогр ми дорого коштують. к, н прикл д, в 2008 році було виділено зр їлю 3 млрд. дол рів, ринок рішень 3 орг ніз ції мережецентричних бойових дій сягнув обсягу в 200 млрд. дол рів. комп'ютериз цію 5-го рмійського корпусу було витр чено 4 млрд. дол рів. ей корпус був основною уд рною силою ко ліції у війні з р ком і проходив випробув ння у бойових діях як комп'ютеризов не в ійськове об'єдн ння.

війні $з$ р ком результ т к мп нії вирішили високі інформ ційні технології (рис. 3):

- військ ко ліції вступ ли в бій, не турбуючись ні про тил, ні про попередню розвідку цілей інформ ція, п ливо і боєприп си н дходили в потрібний ч с і точно з призн ченням;

- мерик нські офіцери не користув лись к рт ми, використовув ли систему бойового упр вління FBCB2, як дозволяє в л нці бриг ди (б т льйону) доводити інформ цію до кожного солд т ;

- всі ком ндири т ртилеристи м ли мобільні комп'ютери в особливо з хищеному корпусі;

- інформ ція поступ л від супутників, літ ків, екіп жів т нків, і окремих піхотинців;

- опер тивність н ведення н цілі дуже висок : $80 \%$ бойових вильотів почин лись «н осліп», інформ ція про цілі поступ л від н земних ч стин тільки н передовій;

- комп'ютери шт бу 5 відслідковув ли до 1000 н земних цілей н годину, вн слідок чого кількість уд рів, н несених , виросл до $80 \%$.

ля орг ніз ції дресного з безпечення у війні проти р ку використовув л сь систем MTS, як безперервно відслідковув л місцезн ходження всіх н земних об'єктів до окремого - сього було з діяно близько 4000 бортових комп'ютерів і 1000 серверів. оступ - 3 особливим п ролем. ожний солд $\mathrm{T}$ i його історія хвороби 3 несен ий комп'ютерний облік, 6 з д них з'єдн н 3 тиловою тр нспортною системою. 


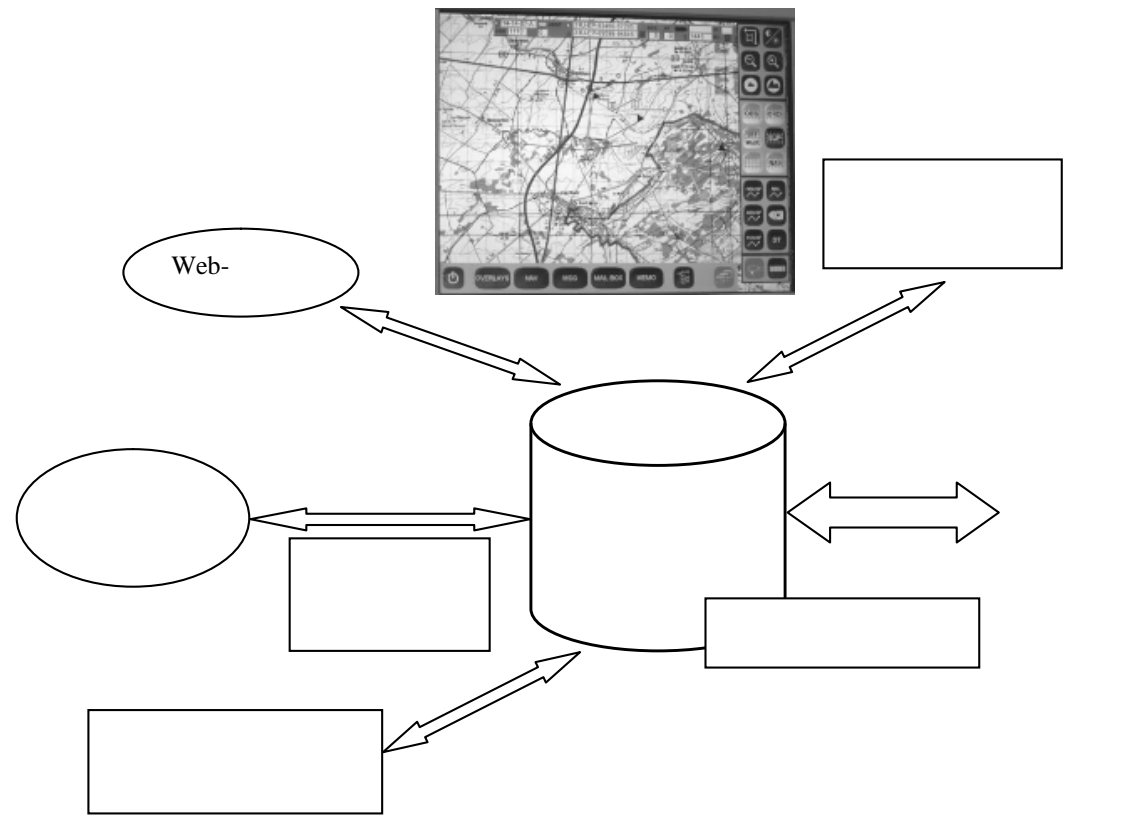

ис. 3. труктурн схем перспективної моделі з безпечення вз ємодії втом тизов них систем упр вління ко ліційних сил

\section{ИСНОВ КИ}

сьогоднішній день дещо по-іншому вигляд є систем упр вління військ ми у кр їн $\mathrm{x}$ в порівнянні з системою упр вління у бройних ил $\mathrm{x}$ кр їни.

е ліз ція 6 зових положень концепції ведення бойових дій 3 використ нням єдиного інформ ційного простору спрямов н $\mathrm{H}$ под льше скорочення циклу «розвідк - уд р», що дет лізує й одноч сно об'єднує чотири принципи бойових дій розвідку, оцінку обст новки, прийняття рішення i н несення уд ру.

уч сний ст н бройних ил кр їни в період розпоч того, ле не з вершеного ре формув ння, обмеженого фін нсув ння, ст н військовопромислового комплексу т ст н військової техніки й озброєння є проблем тичними у створенні єдиної втом тизов ної системи упр вління військ ми.

ле у зв'язку з орієнтув нням реформув ння бройних ил кр їни н ст нд рти використ ння передових технологій у створенні втом тизов них систем упр вління є тим шляхом, яким повинно рух тись реформув ння цього н прямку.

\section{писок літер тури}

1. оровиков. остояние и перспективы р звития ком ндно-измерительного комплекс

оровиков // рубежсное военное обозрение. - 2008 № 3. - . 55-59.

2. омов . . 6 эволюции современной мерик нской доктрины «информ ционных опер ций»/ омов . ., оротков . ., ылевский . .// оенн $я$ мысль. - 2008. - № 6. - . 54-61.

3. ршин . о лиционные опер ции проблемы вз имодействия втом тизиров нных систем упр вления $и$ пути их решения / ршин ., ож нов . // рубежнное военное обозрение. 2008. № 4. - . 13-19.

4. ршин. о лиционные опер ции проблемы вз имодействия втом тизиров нных систем упр вления $и$ пути их решения / ршин ., ож нов . // рубежнное военное обозрение. - 2008, № 5. - . 16-22.

5. ельцов. . точнение подходов к созд нию системы воздушно-космической обороны госуд рств в условиях сетецентричных войн будущего / . . ельцов // оенн я мысль. - 2008. - № 9. - . 2-10.

6. John Luddy. The challenge and promise of networkcentric warfare. - Arlington: Lexington Institute, 2005. - 15 p.

7. David S. Alberts. Network-centric warfare: Developing and Leveraging Information Superiority / David S. Alberts, John J. Garstka, Frederick P. Stein - Library of Congress Cataloging-in-Publication Data - CCRP publication series 2000. $-284 p$.

дійшл доред кції 9.12.2008

ецензент: доктор технічних н ук, ст рший н уковий співробітник . . орольов, ьвівський інститут ухопутних військ, ьвів 
. . олищук, . . илимонов

ст тье н лизируется состояние дел по упр влению боевыми действиями вооруженных сил и других госуд рств в р зных звеньях упр вления (от стр тегического до т ктического) н поле боя с использов нием передовых информ ционных технологий.

лючевые слов : системы упр вления, единое информ иионное простр нство, информ ционн я сеть, сетецентрические войны.

\title{
ANALYSIS OF SOME COMMAND SYSTEMS OF ARMED FORCES OF NATO COUNTRIES AND OTHER STATES
}

\author{
L. I. Polischuk, S. N. Filimonov
}

The article deals with the progress in combat ac tions command of Armed Forces of NATO and other states on different levels of command (from strategic to tactical) on battlefield with the application of advanced information technologies .

Keywords: command systems, single information space, information ne twork, net-centric wars.

\subsection{2}

. . $\mathrm{p}$ сник, . . опович, . . $\mathrm{p}$ сник, . . озув тенко

ввівський інститут ухопутних військ, ввів

ля вирішення проблеми низької ефективності н ви льно-тренув льних з собів $i$ ухопутних військ необхідно м ти вл сні погляди н розробку $m$ осн щення системи опер тивної $m$ бойової підготовки роду військ н вч льно-тренув льними з соб ми, н ви льним $i$ полігонним обл дн нням. трим ні результ ти являють собою ряд конкретних пропозицій щодо з г льних н прямків розвитку н ви льно-тренув льних з собів $i$ ухопутних військ, ролі і місия н вч льно-тренув льних з собів $i$ в процесі бойової $і$ опер тивної підготовки, комп'ютерних форм н вч ння в трен жно-моделюв льній системі $i$. езульт ти можуть бути використ ні в інтерес $x$ i з пит нь викон ння дослідних $i$ дослідно-конструкторських робіт щодо модерніз ції, створення $і$ використ ння в н вч льному процес $i$ н ви льно-тренув льних з собів $m$ відпр цюв ння технічних з вд нь для них, $m$ кож для обгрунтув ння н прямків розвитку н вч льно-тренув льних з собів інших родів військ ухопутних військ.

лючові слов : $p$ кетні військ $i$ ртилерія, бойов $m$ опер тивн підготовк, н вч льно-тренув льні з соби, н ви льно-тренув льний процес, трен жер, трен жнн-моделюв льний комплекс, трен жсномоделюв льн систем , комп'ютерні форми підготовки, комп'ютерний центр бойової підготовки.

\section{ступ}

ост новК

тренув льні з соби ( ) відігр ють в жливу роль у системі бойової підготовки підрозділів і ч стин бройних ил, в тому числі р кетних військ i ртилерії ( i ) ухопутних військ. лід відзн чити, що н йбільш широке їх використ ння в пр ктиці військового н вч ння прип д є н кінець 80-х років минулого сторіччя, коли комп'ютерні технології ст ли спроможними здійснюв ти моделюв ння опер тивно-т ктичної, л ндш фтної т клім тичної обст новки й імітув ти дин міку руху військової техніки, функціонув ння іiі систем т озброєння. н ліз ситу ції, як скл л ся н нинішній ч с у системі бойової т опер тивної підготовки i , пок зує, що рівень використ ння т ефективність бойової т опер тивної підготовки різко знизились. ричини цього м ють комплексний х p ктер i $\mathrm{x}$ р ктеризуються н ступними чинник ми:

- невідповідністю технічного ст ну вимог м суч сного н вч льно-тренув льного процесу ( $\quad$ ); - невизн ченістю н прямків модерніз ції і ; - низьким рівнем методичного з безпечення використ ння н явних .

н ліз ост нніх досліджень і публік цій. роблемі з безпечення н лежного рівня бойової

( ) . . p сник, . . опович, . . р сник, . . озув тенко 